\title{
Reducing Microbial Pollution in European Coastal Waters: The Challenges of a New Era
}

\section{Carlos JA Campos*}

Centre for Environment, Fisheries and Aquaculture Science (Cefas), Weymouth Laboratory, UK

Over the last couple of decades, substantial investment has been made in many European countries to improve point-source discharges from sewerage plant and infrastructure [1]. European Union environmental legislation has been the main driver for these improvements, namely the Urban Wastewater Treatment Directive (UWWTD), Bathing Waters Directive (BWD) and Shellfish Waters Directive (SWD). Perhaps, the most thoroughly documented example of the benefits of improved sewage treatment is the increase in the number of coastal and inland bathing waters that consistently achieve compliance with the guideline bacteriological standards of the BWD [2]. Despite this progress, it is now evident that microbial pollutants from diffuse water pollution from agricultural (DWPA), and urban areas contribute a larger proportion of bacterial contaminants delivered to coastal waters than previously thought, and are causing problems for bathing and shellfish waters compliance. Although the impact of DWPA has long been recognised, improvements have been slow and difficult because of the complexity associated with the multiple pollutant transport pathways that are characteristic of this type of pollution. An example of this is the England Catchment Sensitive Farming Initiative, the most comprehensive programme of work carried out to date to identify and reduce DWPA in England. Under the programme, advice has been given to thousands of farmers in 50 catchments covering $40 \%$ of the nation's agricultural land. Despite some good examples of partnership working at local level, a programme evaluation report by the National Audit Office concluded that work to date has not proved value for money because important information gaps still exist on the causes of diffuse pollution, and there has been little progress in persuading those causing most diffuse pollution to acknowledge their responsibility [3]. A significant impediment to the effectiveness of the UWWTD in contributing to reduce sewage pollution relates to the fact that this legislation applies to urban agglomerations of 2,000 people or more, and thus limited scope exists to minimise public health risks in rural areas. Looking ahead, major investment will be needed to maintain sewerage infrastructures compatible with future demographic and land use changes [4].

A topic of particular concern is the growing evidence that enteric viruses are probably widespread contaminants of the marine environment $[5,6]$. These viruses produce discernible adverse effects on human health, including diarrhoea, self-limiting gastroenteritis, respiratory infections, hepatitis and diseases associated with high mortality rates [5]. In particular, human noroviruses (NoV) are known to be responsible for the majority of shellfish-related gastroenteritis reported to epidemiological surveillance authorities [7]. Probably no effect of microbial pollution has captured more public attention than shellfish-related gastroenteritis though, in fact, the real public health burden remains largely unknown. NoV, which have been considered 'the perfect human pathogens', are shed in high numbers, very persistent in the environment, highly contagious, constantly evolving and may cause illness at low concentrations [8]. While environmental influences outside the gastro-intestinal tract of their hosts may cause substantial decay, new evidence suggests that a proportion of viruses released to groundwater may remain detectable for over 3 years and infectious for at least 2 months [9]. The incidence of NoV infections is likely to increase in line with the predicted increase in extreme rainfall events under climate change scenarios $[4,10]$. It is believed that these impacts vary greatly among European coastal regions, depending on the geomorphology of the catchments, human population densities and prevalence of the virus in the community. Increases in pollutant flows due to population growth are a challenge for rapidly growing parts of the continent, particularly those more vulnerable to immigration.

The most effective way of reducing the harmful impacts of microbial contaminants on coastal ecosystems is to eliminate or restrict their release to the environment, and therefore, 'pollution prevention' schemes constitute the first line of defense. Reducing the impact from point-source sewage discharges will require efforts at several scales and programmes that harmonise policies on water resources and quality, and land conservation with coastal environmental quality objectives.

Much of the long-term planning of pollution source control is now 'under the umbrella' of the Water Framework Directive (WFD). There is expectation that the implementation of 'programmes of measures' under this directive will contribute to the reduction of microbial pollution of coastal waters, although it is not clear how this will be achieved for shellfish protected areas, in the absence of a microbiological standard in the WFD equivalent to that of the SWD. It is unlikely that a viral standard would be required in the WFD; however, a NoV standard is likely to be introduced as part of the Food Hygiene Regulations in the near future. Regulatory monitoring programmes that adequately capture the natural spatial and temporal variability of microbial contaminants are required to evaluate the effectiveness of control strategies. To provide grounding for policies needed to protect human health, more research is needed on sources and movements of enteric viruses in the marine environment and related effects on public health. New monitoring technologies and data analysis tools provide breakthrough opportunities to study environmental change over larger spatial and temporal scales in this new era of microbial water quality.

\section{Disclaimer}

The views expressed in this editorial are those of the author and do not necessarily represent the views of Cefas.

*Corresponding author: Carlos JA Campos, Centre for Environment, Fisheries and Aquaculture Science (Cefas), Weymouth Laboratory, Barrach Road, The Nothe, DT4 8UB Dorset, UK, E-mail: carlos.campos@cefas.co.uk

Received August 21, 2013; Accepted August 28, 2013; Published September 03, 2013

Citation: Campos CJA (2013) Reducing Microbial Pollution in European Coasta Waters: The Challenges of a New Era. J Coast Dev 16: e102. doi: 10.4172/14105217.1000e102

Copyright: ( 2013 Campos CJA. This is an open-access article distributed under the terms of the Creative Commons Attribution License, which permits unrestricted use, distribution, and reproduction in any medium, provided the original author and source are credited. 
Citation: Campos CJA (2013) Reducing Microbial Pollution in European Coastal Waters: The Challenges of a New Era. J Coast Dev 16: e102. doi: 10.4172/1410-5217.1000e102

Page 2 of 2

\section{References}

1. European Environment Agency (2013) Urban waste water treatment (CSI 024). EEA, Denmark.

2. European Environment Agency (2013) European bathing water quality in 2012 EEA Report No 4/2013, Denmark.

3. National Audit Office (2010) Tackling diffuse water pollution in England. Report of the National Audit Office to the Environment Agency. The Stationary Office, London, UK.

4. Martin J, Henrichs T, Pirc-Velkavrh A, Volkery A, Jarosinska D, et al. (2010) The European environment-State and outlook, 2010: Synthesis. European Environment Agency, Copenhagen, Denmark.

5. Fong TT, Lipp EK (2005) Enteric viruses of humans in aquatic environments: Health risks, detection, and potential water quality assessment tools. Microbiol Mol Biol Rev 69: 357-371.
6. Cantalupo PG, Calgua B, Zhao G, Hundesa A, Wier AD, et al. (2013) Raw sewage harbors diverse viral populations. mBio 2: e00180.

7. European Food Safety Authority (2011) Scientific opinion on an update on the present knowledge on the occurrence and control of foodborne viruses. EFSA J 9: 2190-2196.

8. Hall AJ (2012) Noroviruses: The perfect human pathogens? J Infect Dis 205 1622-1624.

9. Seitz SR, Leon JS, Schwab KJ, Lyon GM, Dowd M, et al. (2011) Norovirus infectivity in humans and persistence in water. Appl Environ Microbiol 77: 68846888.

10. Part P, Jarosinska D, Hoogeveen Y, De Saeger E, van Dingenen R, et al. (2013) Environment and human health. Joint EEA-JRC report EUR 25933 EN, No 5/2013, Denmark. 